\title{
THE INTENSIVE USE OF LIGHT LAND
}

\section{J. D. STEWART}

Lincoln College, Canterbury

IT is estimated that there are three-quarters of a million acres on the Canterbury Plains which can be classified "light land", a classification which is a little vague, but sufficiently understood for there to be no need to attempt to define it here.

In the past, the term has been adequate and versatile. However, intensification of farming systems in recent years has focused attention on important differences. In particular, variations in effective rainfall and its distribution, and in soil profile-depth to the gravel-become more significant as production pressures are increased. More critical evaluations of the best farming systems are then necessary. For example, where either a mean rainfall of 30 in. or a soil profile showing 12 to 15 in. to gravel, or both, occur, intensification may take the form of a mixed sheep and cash cropping system. High outputs and profits with such a system are being achieved by farmers who have tight cropping systems, efficient land utilization and high stocking on grazing areas which are reduced to the minimum considered necessary for fertility maintenance. The soil boundaries of profitable cash cropping have been pushed back on to light land in recent years by the application of these principles.

Rankin (1965) reported that on his 600-acre property at Pendarves he was growing approximately 100 acres of crop (wheat, partridge peas, grass and clover seed) while running 1,700 ewes, 450 ewe hoggets, wintering 600 wether hoggets and 20 two-year-old cattle. Stocking rate was 4.6 ewe equivalents on the available grazing area and stock performance was high, lambing $112 \%$, and wool weight $12 \mathrm{lb}$ per ewe.

Subsequently intensification has taken the form of expansion in the area cropped as well as further increases in sheep numbers (Table 1).

Rankin's soil profile consists of 4 to 6 in. silt loam, with few stones, over a subsoil of 8 to $10 \mathrm{in}$. This is a somewhat "superior "light" soil, but the management demonstrates that a high standard of farming, with emphasis on soil fertility through balanced rotations and high stocking, can 
INTENSIVE USE OF LIGHT LAND

TABLE 1: PROPERTY D. E. RANKIN, PENDARVES

(Area: 600 acres. Lismore stony silt loam)

\begin{tabular}{|c|c|c|c|}
\hline & 1964-5 & $1966-7$ & $1968-9$ \\
\hline Breeding ewes & 1,700 & 2,050 & 2,300 \\
\hline Ewe hoggets & 450 & 500 & 550 \\
\hline Wether hoggets & 600 & 700 & 500 \\
\hline Area harvested & 80 & 180 & 252 \\
\hline E.E.s/available spring acres …………...... & 4.4 & 6.7 & 7.1 \\
\hline Wool per sheep & 12.8 & 12.5 & 12.1 \\
\hline Interest surplus/acre & $\$ 9.0$ & $\$ 17.6$ & $\$ 17.2$ \\
\hline
\end{tabular}

give levels of technical and financial performance until recently thought to be possible only on much stronger soils. 1969 experience confirmed that, in a year of very severe drought, there would be serious depression of income on such farms.

An adjacent farmer, on 500 acres of soil with the same classification but probably thinner, Cameron (1968), has placed the emphasis in his intensification programme on sheep at high stocking rates. In a rapid intensification phase, emphasis has been placed on per-acre output. Table 2 summarizes the results achieved on this property.

TABLE 2: PROPERTY B. K. CAMERON, PENDARVES (Area: 500 acres. Lismore stony silt loam)

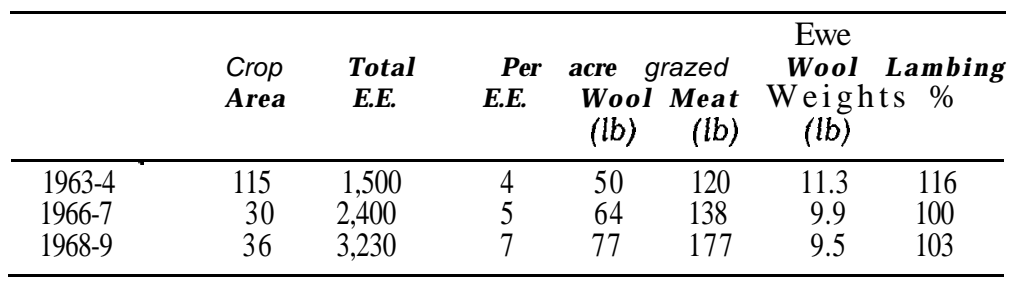

B. K. Cameron (pers. comm.) now believes that he has reached the maximum level of technical performance he can achieve with existing knowledge of dryland methods. His next step in intensification is spray irrigation, which will be used particularly to ensure lucerne hay from spring growth, fodder beet yields for winter feeding, and autumnsown greenfeed for lambing.

These two examples have been used because they demonstrate alternative systems of intensive use of light land, each of which has been technically and financially successful. It is emphasized that these systems have been developed 
under a 25 to 27 in, rainfall, with soil moisture below wilting point for 45 to 50 days each summer, and with a high degree of interseasonal variation in effective rainfall.

But the soil- type referred to has significant advantages over much light land. It is the depth to the gravel which is crucial, and the density of stones in the topsoil. The remainder of this paper will be concerned with those areas where the combination of soil profile and effective rainfall is such that grain crop yields are low and unreliable, and where conventional subterranean-clover-based pastures give dry matter yields of only 2,000 to $4,000 \mathrm{lb}$ per annum.

This has been a difficult and unresponsive environment with which to make the kind of progress necessary to meet the continuing decline in farming terms of trade. Irregular summer drought, dry springs and autumns, occasional severe winters, grass grub and porina, and problems of sheep thrift have been the impeding factors. However, it now seems evident that, where lucerne can be successfully grown on these light soils and where appropriate sheep management and grazing policies are adopted, stock production previously thought to be attainable only in more favoured areas can be achieved.

On the Lincoln College light-land farm at Ashley Dene, in 1965, we established a farmlet of 30 acres on transitional Lissnore-Eyre stony silt loam (4 to 6 in. stony silt loam over gravel).

Previously, grazing trials by Iversen (1967) had indicated that an intensive rotational grazing system on lucerne at Ashley Dene cuuld give dry matter yields of approximately $7,500 \mathrm{lb}$, with relatively low variability. On this evidence the farmlet, which in 1965 was a five-year-old lucerne stand of moderate quality, was stocked with five mixed-aged Corriedale ewes per acre. These were mated with Dorset Down rams and the replacement policy was to purchase two-tooth ewes. At this time it was a quite general view that a stocking rate of three ewes per acre on this class of land was high. Indeed, on Ashley Dene as a whole, we were at that time justifiably satisfied with our stocking level of three-and-a-half ewe equivalents.

Feed organization has been based on an intensive rotational system with ewes and lambs, early weaning of lambs on to mature lucerne, foraging of lucerne by ewes in the summer, supplementary where necessary to maintain body weights at levels considered desirable, wintering on turnips and hay, and lambing on lucerne overdrilled with 'Grasslands Tama' ryegrass. 
Sheep performance, particularly wool weights, in the first two years of the demonstration indicated understocking. In the following two years, it was shown that good performance could be achieved at seven ewes per acre, if we were prepared to purchase small amounts of winter feed. Results from the first four years are given in Table 3. The 1968-9 drought was costly to the farmlet in terms of loss of performance and in purchased feed, but no more so than on other farms in the area moderately stocked.

TABLE 3: 30-ACRE FARMLET. ASHLEY DENE.

(Lismore-Eyre stony silt loams)

\begin{tabular}{|c|c|c|c|c|c|}
\hline & \multicolumn{2}{|c|}{$\begin{array}{c}\text { Ewes } \\
\text { per acre }\end{array}$} & \multirow{2}{*}{$\begin{array}{c}\text { Lamb Meat } \\
\text { per acre } \\
(l b)\end{array}$} & \multirow{2}{*}{$\begin{array}{c}\begin{array}{c}\text { Wool } \\
\text { per acre } \\
(l b)\end{array} \\
68\end{array}$} & \multirow{2}{*}{$\begin{array}{c}\text { Feed } \\
\text { Balance } \\
\text { per Ewe } \\
\text { (cents) } \\
+24\end{array}$} \\
\hline $1965-6$ & 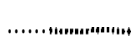 & 5 & & & \\
\hline $1966-7$ & 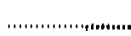 & 5 & 175 & 61 & +18 \\
\hline $1967-8$ & 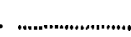 & 7 & 206 & 79 & -54 \\
\hline $1968-9$ & 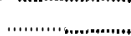 & 7 & 238 & 86 & 48 \\
\hline $1969-70$ & …………. & 7 & 200 & 66 & -150 \\
\hline
\end{tabular}

It is our intention to increase the stocking rate to eight ewes per acre in 1970.

The main value of a farmlet type demonstration such as this is not necessarily that it establishes practical farming standards. But it does indicate the management techniques and adjustments we have to adopt, with the present stage of our knowledge, if we want stocking rates at these levels.

For example, if we want to run seven ewes per acre, then we would have to have a particular attitude to feed conservation. We would have to accept the purchasing of feed as part of the management system. There is little doubt that this would pay. Computer analysis carried out in the Farm Management Department at Lincoln College (Taylor, 1967, R. J. Townsley, unpubl. data) indicates that under a wide range of price and technical assumptions it is more profitable to feed lucerne in situ with ewes and lambs than it is to make it into hay. Feed reserves would then be built up from external sources-e.g., threshed straws and grain-and basic reliance placed on turnips and greenfeeds. But this is a management strategy which, as yet, has little appeal to farmers and its practicability requires further testing.

The remainder of this paper is devoted to suggesting a management system for a stocking rate on light land of 
about five ewes per acre, which can be regarded as sufficiently intensive to conform to the title.

\section{LAND USE}

The aim would be to have the whole farm in 'lucerne, less areas in the process of renewal through a forage Cropping rotation. There have been occasions in the past (Stewart, 1967) when I have hesitated on this matter because of doubts about balance and flexibility in feed supply, but this now seems unnecessary. With lucerne we have a pasture which produces more feed, of higher quality, with less inter-seasonal variability. It is resistant to grass grub and porina, fertilizer requirements appear to be moderate at high. stocking rates, and stock thrift is excellent provided trace element deficiencies are identified. Lucerne renewal would be through a simple rotation of greenfeed to turnips to new lucerne, spring sown. The spring sowing of lucerne is a weakness in the system, since this area is then out of production during the September-October feed bottleneck. Given reasonable moisture conditions in January or February, the undersowing of winter forage with the lucerne is possible. We are currently having a fresh look at this practice.

$\because$ I would expect to renew about 50 acres of lucerne a year. Pre-lambing greenfeed would be provided by the 50 acres in the rotation and by overdrilling in autumn 50 to 100 acres of old lucerne stands, the area depending on the autumn moisture conditions. The greenfeed variety, assuming the price of the seed is reasonable, would be Tama ryegrass.

TABLE 4: LAND USE AND FEED RECONCILIATION, 500-ACRE LIGHT-LAND FARM

\begin{tabular}{|c|c|c|c|c|}
\hline & Winter & Ewes & $\begin{array}{c}\text { Lambing } \\
\text { to } \\
\text { Weaning }\end{array}$ & Ewes \\
\hline \multicolumn{5}{|l|}{ Lucerne } \\
\hline Grazing & 100 & 300 & 320 & 2,300 \\
\hline Hay _ - ب - & - & 1,000 & 80 & \\
\hline Overdrilled - & 75 & & - & \\
\hline 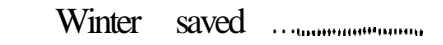 & 225 & & & \\
\hline New $\quad$............ n & - & & 50 & \\
\hline 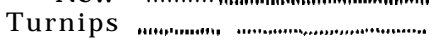 & 50 & 1,250 & 一 & \\
\hline \multirow[t]{2}{*}{ Greenfeed } & ,.⿲丿 50 & & 50 & 200 \\
\hline & 500 & 2,550 & 500 & 2,500 \\
\hline
\end{tabular}


Land utilization and feed reconciliation under this system are summarized in Table 4. I would expect to have surplus hay in some years, deficits in some. This would be buffered by periodic purchases of threshed straw, and grain. If there was land on the farm capable of growing at least 40 bushels of barley per acre, I would consider growing this and bulk storing.

\section{STOCK MANAGEMENT}

A vastety of breeding and replacement policies is practicable. A Corriedale flock, with replacements bred, or purchased as two-tooth or cast-for-age ewes is common, while the first-cross Border Leicester-Corriedale has adherents. A recent computer analysis of alternative sheep policies on light land has demonstrated that at current wool and lamb prices there is little difference in profitability between many of these alternative policies (R. J. Townsley, unpubl. data).

There would be management advantages with a flock of adult Corriedale ewes maintained by buying in cast-for-age ewes and replacing approximately one-half each year. This system gives scope for summer destocking, easing feed demand in the summer months. Under current wool and lamb prices this system budgets out favourably against other policies, but its main limitation from the viewpoint of many farmers is the large draft of ewes which has to be bought each year. It is a system more acceptable to those with smaller flocks.

Because my 2,500-ewe farm is to be a one-man unit, with some casual and contract labour only, I would opt for the simplest, least-labour system, with easy care sheep. This would be a first-cross Border-Corriedale flock, with replacements purchased as ewe lambs, as it is unlikely that satisfactory lines of older ewes would be obtainable. I would look for early-born ewe lambs which could be mated in late April.

These ewes would be mated with fat-lamb rams with high performance backing in respect to lamb growth rates. A key feature of management would be late lambing (mid- to late September), aiming for a full synthesis of feed supply and demand. On the winter-saved areas of lucerne, I would expect a good bank of growth by this time, to facilitate an intensive rotational grazing system with the ewes and lambs. Lambing would be synchronized to minimize spread, and I would expect to be drafting lambs at 8 to 10 : weeks and to be weaning at the same age. If there were feed 
stresses obviously building up, lambs could be weaned at s1x weeks., It would require a substantial premium for early lambs to encourage me to depart from late lambing, except perhaps with the one-year ewes. It should be emphasized that this viewpoint relates only to the high lucerne farm and not to light-land farms with a high ratio of conventional pastures.

The final point I should have to resolve would be paddock size in relation to size of mobs and grazing frequency over the lambing to weaning period. I have previously understood that for maximum efficiency of the lucerne plant rapid grazing is desirable. This creates problems related to the cost of subdivision, water reticulation, sheep disturbance and labour requirements. If, as I understand we may now be advised, the productivity of lucerne will not be impaired if the grazing period within the rotation is lengthier, then these problems will be less important. We have still to acquire experience in the management of lucerne over this period in order that we can reconcile the requirements of the plant physiologist and the animal scientists, with the day-to-day management routine of the farm.

\section{REF'ERENCES}

Cameron, B. K., 1968: Proc. N.Z. Grassld Ass., 31: 44-9. Rankin, D. E., 1965: Proc, 15th Lincoln Coll. Fmrs' Conf.: 43-7.

Iversen, C. E., 1967: Grazing management of lucerne. In The Lucerne Crop, R. H. M. Langer (ed.), A. H. \& A. W. Reed, Wellington. Taylor, N., 1967: A Management Study of Light Land Farming in Canterbury, New Zealand. M.Agr.Sc. thesis, Lincoln Coll., Univ. of Canterbury. (Lodged in Lincoln Coll. Library.)

Stewart, J. D., 1967: Lucerne in the farm programme. In The Lucerne

Crop, R. H. M. Langer (ed.), A. H. \& A. W. Reed, Wellington.

\section{DISCUSSION}

To a question from Wedin (U.S.A.) concerning the need for potash on the light lands described, Stewart replied that it was not necessary, particularly under the grazing regime advocated. It might be needed under an intensive haying system. Inglis asked if cattle could be used on such light land in conjunction with sheep and what effect would they have on the lucerne. Stewart stated that he would not use cattle under his system on light land. Some farmers were running cattle successfully but not at high stocking rates. Comment was made by a farmer that, in his district (Lower Awatere), it was the practice to sow lucerne in the spring with a cover crop such as barley. The crop could be fed off if feed were short or could be harvested as grain. Autumn sowing was difficult because of weed competition, particularly subterranean clover. Stewart stated there were many. ways of sowing lucerne and agreed that using cereals 
as a cover crop could be moderately successful. However, the farmer would need to assume that he would get at least 35 bushels of grain per acre, and good lucerne establishment. They had passed through the subterranean clover competition phase at Ashley Dene, but he conceded that it could be severe if the buried seed population was very high. Douglas questioned the wisdom of ploughing up good lucerne stands to sow turnips and greenfeed. Stewart replied that, under the ideal grazing system where the longevity of luceme stands could be 12 to 15 years, we could be ploughing up good ones. In that case it might be better to overdrill with Tama ryegrass plus nitrogen and thus avoid unnecessary ploughing up. Asked by Vartha to speculate on the use of irrigation to produce increased autumn growth, Stewart said that he had been speaking of the use of light land without water. It certainly did not pay where the farmer was simply superimposing irrigation on a standard dryland system. O'Connor wondered if Stewart was prepared to subdivide his flock on his model farm. Stewart replied that 2,500 ewes would be too many for one mob and it would be much more practical management to have mobs of 6-700. He would thus have three or four mobs over the tailing to weaning period. Asked if he had profitability figures for his hypothetical farm, Stewart stated that he did not. However, given reasonable capitalization it would definitely be a profitable one-man unit at present prices. He felt at this stage that he should comment on gross margins figures that had been used quite extensively in other papers. He thought that gross margin could be a very dangerous concept. It disregarded fixed costs which should never be done. Its use was only for looking at marginal changes where, say, there had been merely an adjustment of more sheep for cattle. 